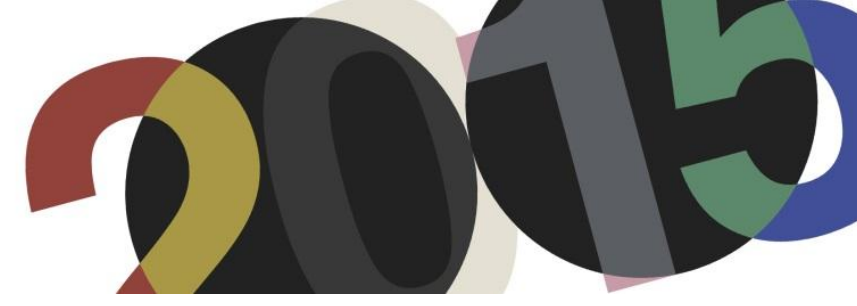

DOI: http://dx.doi.org/10.4995/LC2015.2015.927

\title{
Memory and change through Le Corbusier. Fragments of urban views
}

\author{
F. Gorgeri
}

Department of Architecture - DIDA - University of Florence

\begin{abstract}
In the urban project of Le Corbusier the relationship between new and existing is opportunity of poetic composition. The real traces of the past of one place are transformative tools by which the new project is developed. The projects after World War II, like reconstruction project of Saint-Dié, are occasions to reflect about the new urban developments, rapid and extensive, and the relation of them with the landscape in a new territorial vision. The fragments of past and the new buildings are seen like belonging to a same context of reference and the entire urban composition forming part of a landscape on more large scale. Therefore, the urban project is an ensemble of architectural objects and nature that are held together by calculated visual relation. It is a kind of montage of urban views related to the dimension and measure of the human subject, like visual points or pedestrian paths. Memory and change are linked together by the natural history process and commensurate also to the human measure by a three dimension urbanism where the architecture can anew make the city.
\end{abstract}

Resumen: En el proyecto urbanístico de Le Corbusier la relación entre la nueva y la existente es la oportunidad de la composición poética. Las huellas reales del pasado de un lugar son herramientas de transformación por el que se desarrolla el nuevo proyecto. Los proyectos después de la Segunda Guerra Mundial, como el proyecto de reconstrucción de Saint-Dié, son ocasiones para reflexionar acerca de los nuevos desarrollos urbanos, rápidas y amplias, y la relación de ellos con el paisaje en una nueva visión territorial. Los fragmentos del pasado y los nuevos edificios son vistos como pertenecientes a un mismo contexto de referencia y toda la composición que forma parte urbana de un paisaje de más gran escala. Por lo tanto, el proyecto urbano es un conjunto de objetos arquitectónicos y la naturaleza que se mantienen unidas por la relación visual calculada. Es una especie de montaje de vistas urbanas relacionadas con la dimensión y la medida del ser humano, al igual que los puntos visuales o caminos peatonales. La memoria y el cambio están unidos entre sí por el proceso de la historia natural y acorde también a la medida humana por un tres dimensiones urbanismo donde la arquitectura de nuevo puede hacer de la ciudad.

Keywords: urban project; landscape; memory; Saint-Dié.

Palabras clave: proyecto urbano; paisaje; memoria; Saint-Dié. 


\section{Introduction}

The relationship between new and existing in architectural and urban things is considered by Le Corbusier as opportunity of poetic composition in which the architectural work is the subject and the transformative tool of the dynamic action of the time, whether it understood as a phenomenological and perceptive path both as historical and social aspect.

The remains and relic of the pass are seen as traces of signs and objectual fragments to relocate them in a new urban reality, according to a calculated "acoustic visual"1 that restores a dynamic balance between the parts and pieces in question, able to re-connect the past to the present in a heterogeneous continuity.

The destructive action by the Second World War and the transformative quickness of general relations in the territory have changed approaches and intervention planning. It is an interruption of historical continuity that requires to rethink the relationship with time and the concepts of new and progress, valid until then.

In this irreversible modification of the past, Le Corbusier see a solution of continuity from which can be born new life and new architecture.

Therefore, he adopts a new poetic measure that even more refer to geographical dimension and landscape and in the same time more closely linked to the human scale. In particular, the project for the reconstruction of the city of Saint Dié, generated between April 1945 and February 1946, is an opportunity to reflect on the principles and theories developed until that moment and starting point and reference, an incipit or better a "prototype"2 and a "drapeau", for future projects, as the pilot plan for Bogotà, where coexist past and present, nature and artifice, reality and imagination, objects and traces of the contest with memories of spatiality already lived elsewhere.

\section{Recostruction plan for Saint Dié like prototype}

"The war sparked the era of the movement, a fracture of crystallization, the start of works so wide that we can include since today the architecture and town planning. [...] Never forget the fundamental need for an overall plan [...] provisional element could serve as a model for future endeavors [...] and become the first social organizations [...]: the barracks of wartime will become the inclined plan that leads to the social achievements; its multifaceted existence will bring generating functions of life ". ${ }^{4}$

The city of Saint Die des Vosges, located in the Lorraine region on the border between France and Germany, was destroyed by retreating German troops between 8 and 14 November 1944.

It is a cityscape enclosed within urban walls, with the limit of the river at south and of the Vosges at north, grown up around a commercial area, dominated by a gothic cathedral and characterized by narrow streets between buildings and a main street, the rue Thiers, to which it is added the twentieth-century development determined by the textile industry in the south of the area and at the side of the railway track.

\footnotetext{
${ }^{1}$ Le Corbusier: "Il cuore della città punto d'incontro delle arti. Acustica visiva", in Rogers, Ernesto Nathan; Sert, Josep Lluis; Tyrwhitt, Jaqueline (edited by): CIAM 8. Il cuore della città: per una vita più umana delle comunità. Milano: Hoepli,1954. p. 46.

${ }^{2}$ Le Corbusier: Euevre Complete. 1938-1946. Zürich: Girsberger, 1946. p. 133.

${ }^{3}$ Ibidem

${ }^{4}$ Le Corbusier: "I problemi della ricostruzione. Quando la pace tornerà sulle strade" in De Carlo, Giancarlo: Le Corbusier. Milano: Rosa e Ballo, 1945. pp. 145-147. Original text in Le Corbusier: Le quatrês route. Terres, air, fer, eau. Paris: Gallimard, 1941.
} 
More than ten thousand people are evacuated and then the part of town north of the river Meurthe, the area between the cathedral and the business district, and a narrow band over the other side of the river, are burned with mines and grenades, saving only the peripheral areas, further south. The textile city of about twenty thousand inhabitants shows extensive damage and more than ten thousand people are homeless.

By the subsequent arrangement of the rubbles in tas de pierres, where were urban blocks, the urban morphological structure emerges clearly in its parts, as a scheme of zoning and paths in the landscape.

In this devastated landscape, only the cathedral at north and the church beyond the river Meurthe, as well as the building of railway station, stand still up, connected visually and physically by the main street.

Destructions and rubbles are signic traces of the formal and social history of the city, to which to give continuity in the opportunity of the needed transformation itself.

They reveal a system of permanent signs and unexpected relationships from which the geographical background, the existing territorial structures and the landscape dominants resurface and to which the social ties that have generated the settlement, were and remain anchored.

“[...] La destruction à peu près complète de l'anciènne ville a eu comme effet de dégager et de remettre en valeur le paysage environnant qui est agréable et charmant. C'est une révélation pour le visiteur et plus encore pur l'habitant. Trésor retrouvé [...]", 5

“La zone déstruite est un rectangle rasé à la granade et par l'incendie, qui était le berceau même de la ville, le lieu où elle nacqui et commença de s'édifier". 6

So, in Saint Dié, the destructive event is subjected to an interpretive and poetic reading of the morphology and of the new spatialities that the inflicted wounds have reopened. The reading of the territorial spatiality, made possible by new visual perspectives, provides the opportunity for a wide-scale project despite the small size of the valley where is located the city. The topographical and settlement structure which constituted the geography of the place in the stratigraphy of the urban past of Saint-Dié is brought back to a new form in the continuity of a substantial adherence to generative connotations.

\footnotetext{
${ }^{5}$ Musée de Saint-Dié: Le Corbusier et Saint-Dié, Musée municipal de Saint-Dié-des-Vosges, 14 octobre-10 novembre 1987. Saint-Dié: Musée municipal de Saint-Dié, 1987. p. 98. Foundation Le Corbusier Paris - bibliothèque (FLC-b). Letter of Le Corbusier to Raoul Dautry like Ministre de la reconstruction et de l'urbanisme, 21 Decembre 1945 (FLC H3-18-146). Also in: Le Corbusier: "A Plan for Saint-Dié” in Architectural Record, N. 100, October 1946, pp. 79-82 (FLC X1-15:20); Le Corbusier: "Un plan pour Saint-Dié" in Homme et l'architecture, N. 5-6, Novembre-Decembre 1945; Le Corbusier: "Ein plan für Saint-Dié in Werk, N. 33, April 1946, pp. 109-112. See also: Le Corbusier: "Plans for the Reconstruction of France" in Architectural Record, n. 99, March 1946, pp. 92-93.

${ }^{6}$ Ibidem. p. 100.
} 


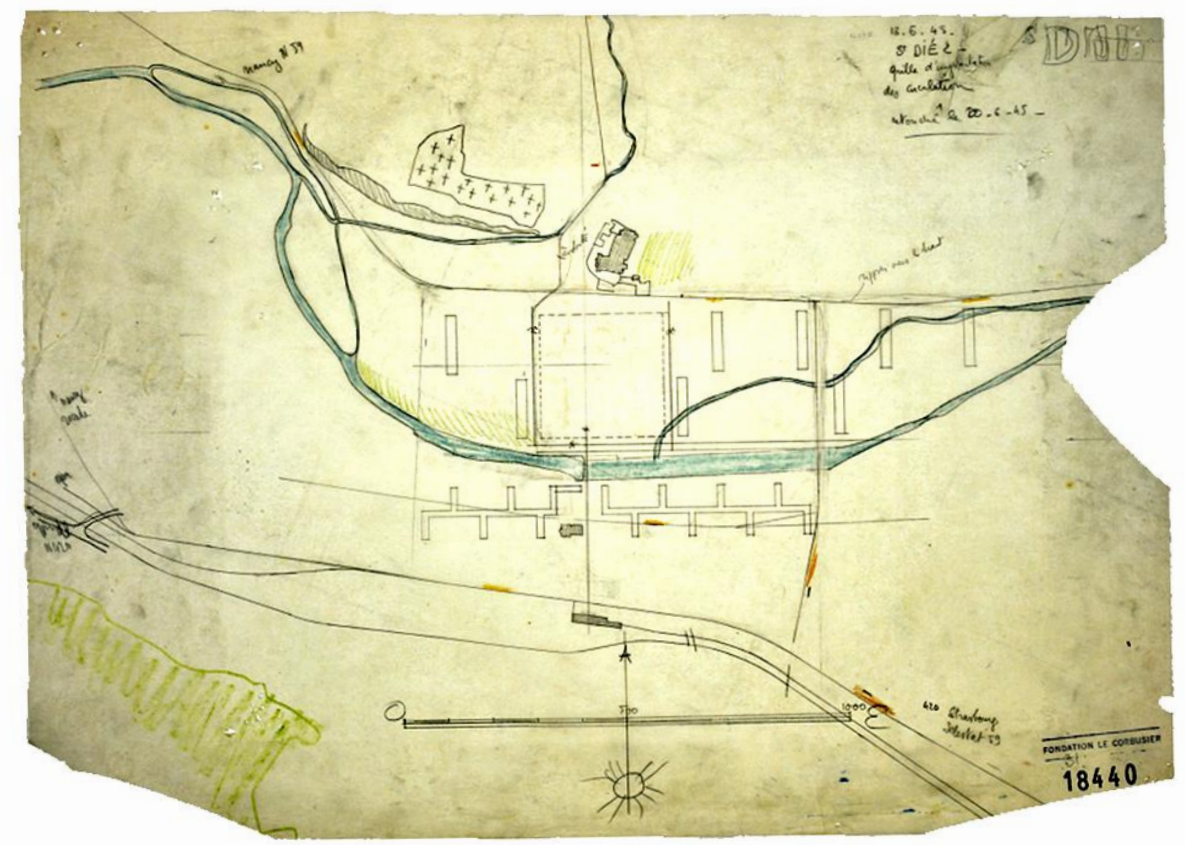

1. Le Corbusier, Sketch for the reconstruction project of Saint-Dié dated 16 June 1945 with the three remaining "fragments" of the destroyed city. 18440 @FLC-ADAGP.

The morphological structure is a kind of urban background track that guides the arrangement of the constituent elements of the project, so that both existing and new things originate by the same basic references.

The first sketches ${ }^{7}$ reveal the reading of the city on a geographical scale, as a compact and figural nucleus present in the landscape and with the elements of it, like river and mountains. Then, the attention is poured on the heart of the city and on what may suggest remained traces of it. The three remaining fragments of the existing city and the trace of the main street, like an ordering axis, are the constituent pieces on which the whole composition is innervated within the territorial context and landscape where it is anchored.

“Après-guerre 1939-1944: la cathédrale et la ville de St-Dié, par exemple. La cathédrale d'abord: la nef romane, privée de ses voûtes, est éclairée violemment, et l'on voit en pleine lumière les chapiteaux dans une splendeur sculpturale glorieuse, que la pénombre seule avait fréquentée jusqu'ici.

Le transept est entier, et l'abside aussi jusqu'au jaillissement des voûtes gothiques dont quelques amorces seulement demeurent encore attachées aux chapiteaux. La messe pourrait être dite dans ce décor extraordinaire, synthétique, symphonique: cette palpitante chose humaine bâtie, et toute déchirée, est installée là comme une épopée au milieu des bêtises quotidiennes. La technique moderne permet de sauver tout cela, permet de l'employer, permet d'y inscrire le souvenir du tragique passé tout récent. Il suffirait d'une dalle de béton portée haut sur de minces potelets extérieurs à la cathédrale, et qui servirait désormais de couverture. La glace de

\footnotetext{
${ }^{7}$ In the spring of 1945, on initiative of his friend Jean-Jacques Duval and the Association Populaire des Sinistrés, Le Corbusier received a request from a town planning study for the city, and on April is named Architecte-Urbaniste-Conseil de la Ville de Saint-Dié. After some sketches, in June Le Corbusier processes the first version of the reconstruction project with a general plan and five detail tables. Cf. Musée de Saint-Dié: Le Corbusier ...cit. See: Sequeira, Marta: Para um espaço público. Le Corbusier e a tradição greco-latina na cidade moderna. Ministério da Ciência, Tecnologia e Ensino Superior. Lisboa: Fundação Calauste Gulbenkian, Fundação para ciência e a tecnologia, 2012. See also: Clericuzio, Peter: "Le Corbusier and the Reconstruction of Saint-Dié. The debate over Modernism in France, 1944-46" in The Chicago Art Journal, N. 20, 2010. pp. 46-71.
} 
Saint-Gobain fournirait en maints endroits les vues sur ces perspectives que j'ai signalées: de nature, de ciel, d'architecture". 8

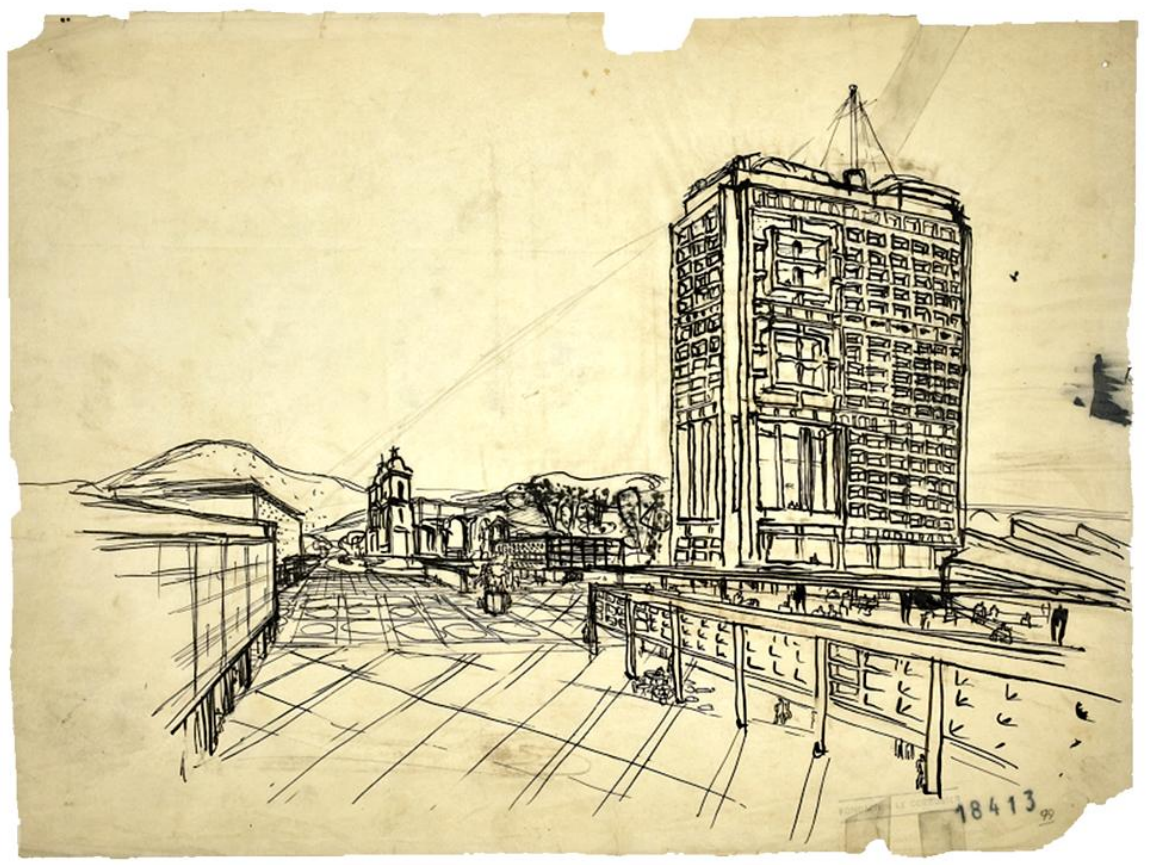

2. Le Corbusier, View through the main axis, old rue Thiers, with the cathedral, the admistrative skyscraper and the mountains on the background, August 1945. 18413 CFLC-ADAGP.

The cathedral is a remained fragment that evokes the whole urbanity and determines a visual pivot in the background of the mountain relief, as well as the civic core is kept as a morphological fragment of socially identity where converges each new settlement part.

The new civic center, the heart of the city, occupies the area of the previous urban centrality with the cathedral which is included among the new functional and formal elements. The cathedral is a connecting link and a space-time hinge: a piece of the common, collective identity and a "message of courage, audacity, temerity"'

The first draft of the project in June 1945 provides already for the arrangement of functional areas and new infrastructures, which will be maintained in subsequent drafts and final version, and a kind of preparation for

"layer" of the addressed issues: in particular, the green system and the relationship with the landscape, the road infrastructures and the pedestrian center, the residential area and the production area, the river as a natural limit at the same time of division and connection between the parts, the urban core as the civic and morphological core.

\footnotetext{
${ }^{8}$ Le Corbusier: "A propos d'architecture d'accompagnement et de respect du passé”, aprile 1946 (FLC), published in Le Corbusier: Le passé à réaction poétique. Paris: Caisse Nationale des Monuments et des Sites, 1988, p. 96. (FLC-b).

${ }^{9}$ Le Corbusier: Maniera di pensare l'urbanistica.[1946]. Roma - Bari: Laterza, 1997. p. 52.
} 


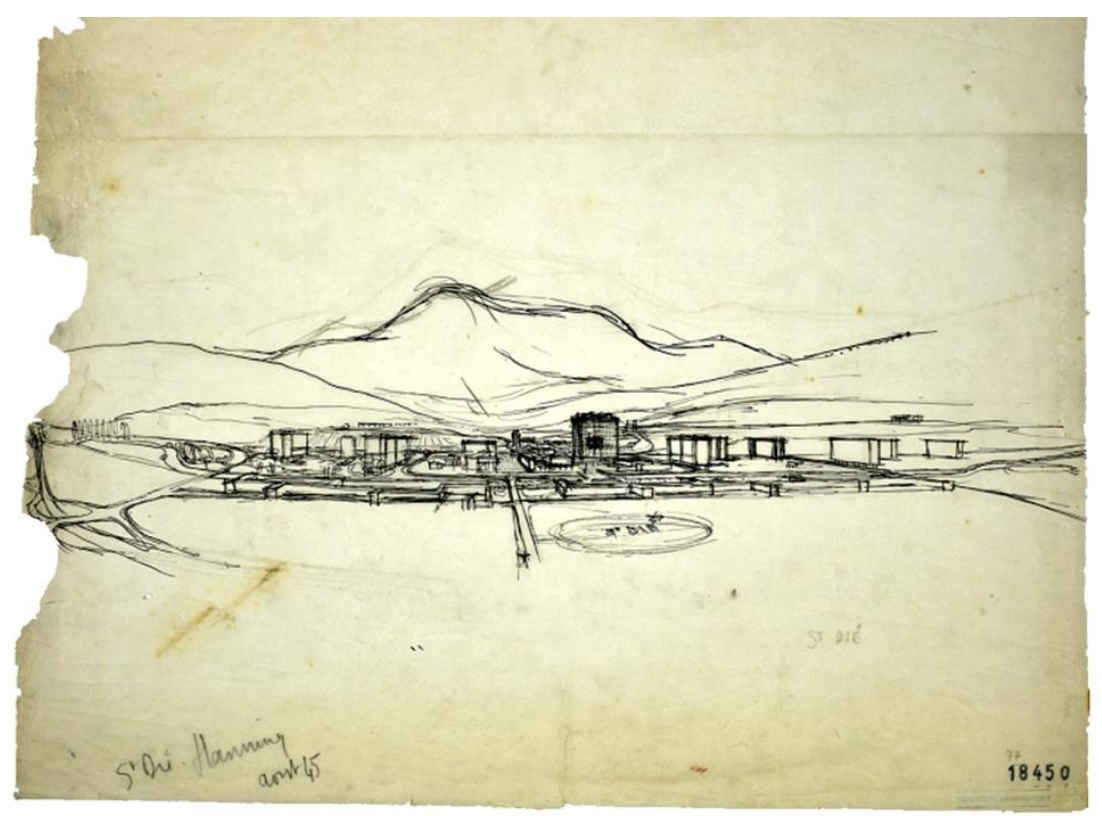

3. Le Corbusier, Overview of the plan for Saint Dié through the main axis and with the mountains on the background. August 1945. 18450 OFLC-ADAGP.

Residences and industrial buildings belong to the landscape and have an extensive nature; the urban core is the civic part, built by and for the community: the public space made up of representative square-agorà as a place of identity, limited and figuratively identified with an ideal quadrangular enclosure of 300 meters on each side.

In this first version of the project are also already included any elements considered "biologically" strictly necessary: residential units (ISAI), administrative offices, coffees, the center of tourism, the Maison Commune, the industrial building.

In the project for Saint Dié the principles set out in the IV CIAM become methodologies tools.The road system is a network connecting to the service of architectural events previously placed in areas with a specific destination: are detected units (housing, working, leisure and circulation) corresponding to areas where the buildings are arranged according to their plastic, volumetric and visual relationship and only later connected by roads. The concept of zone, which corresponds to a part of the city defined by a type of building, breaks the traditional bond between architecture and urbanism and hierarchy connected to the mesh road ${ }^{\mathbf{1 0}}$, but includes a new priority, the landscape: the city is anew characterized by architecture. In this urban composition, the architectural objects look like fragments from different projects and a kind of machines for the vision: they are physical presences linked by perceptive experience and, at the same time, evocative references. The past presences, the landscape and new buildings are the pieces of the new urban composition.

The plan is described as "an arrangement of pure biological elements"11, able to express clearly the functions to which they are intended, according to their forms plastics thought from within outward.

It is also a reflection about duality between center and periphery, residence and workplace, including "sprawling cities and deserted countryside", which still needs to be remedied, restoring the work mode in the experience of the city and the production sites in the morphology of the same. It is indicates a way to return to architecture its fundamental and transformative value, in parallel with the provisions of urban planning and landscape.

\footnotetext{
${ }^{10}$ Cf. Gerosa, Pier Giorgio: Le Corbusier, Urbanisme et mobilité. Basel - Stuttgart: Birkhäuser, 1978.

${ }^{11}$ Musée de Saint-Dié: Le Corbusier... cit. p. 59.
} 
"The city planner is nothing more than the architect", : architecture and urbanisme contribute together to create a new unit ${ }^{13}$, a "unite of conform dimension". The plan can be divided into horizontal registers that identify some functional areas, which are referred to the central area and dimensioned according walking distances.

The heart of the city and of the whole plan is the civic center occupying the old city center.

It is predicted with spaces reserved exclusively for pedestrians. So, the scale of project is the human walking, the right distance between housing and working and the right dimension of the voids between volumes for the good perception of it.

"Le centre civique est le lieu éminent de la cité, son coeur et son cerveau. C'est là que par des monuments et par des actes se développe la vie urbaine et que s'inscrit son histoire",I4.

The medieval morphological structure is taken as an operating fragment of memory for the definition of the project: urban spaces are united with the duality of religious and civic center; the existing main street joins two religious visual fulcrums, two churches, such as testimonial objects and evocative cores and they are also the connecting with the landscape background along with the other new representative buildings.

The heart of Saint Dié, the Chapter, consists of four orthogonal spaces that, as in Mundaneum (1929), representing the action fields of spatial volumes: the tower of the administration center which plays a role of urban landmark, cafeterias and common house like social center, the space of the museum of knowledge like a cultural center and one of the accommodation facilities like a place of tourist reception.

In the design of this civic heart converge also other references that come from the "magic box"15 of the personal memory and spatial experiences, like the square of San Marco in Venice ${ }^{16}$ and the greek agorà. It is a memorial use of the past, also it. With the attitude to considere the process design in continuity and like a kind of anthology of other projects, the civic center recalls the space-volume relationships used in the Palace of the Soviets, the presence of two spatial directions back to the Palais des Nations and the volumes gifted of its own field of visual and proportional action like in Mundaneum. In the same center coexist buildings thought for hypothetical places, like the museum at unlimited growth, together with buildings designed for specific destinations like the halls of the palace of the Soviets or the administrative high-rise for Algier, along with remains of existing buildings like the cathedral.

This heterogeneity and juxtaposition of "pieces" from different architecture allow to design a paratactic composition organized on the basis of a flexible grid, (but geometrical and proportional grid of 25 squares with each side of 60 meters), where the volumes are distribuited according balance weight, of volumes and distance between them. In this composition, the cathedral remains the core of witnesses of the past and focus visual connection with the mountain scenery. The costitutive elements of the city are developed around the axis of the main street to create a series of squares and open spaces according to the principles of pre-existing and duration studied by Lavedan and Poëte.The Grand Rue, rue Thiers, is the traced for the new urban center where there is

\footnotetext{
${ }^{12}$ Le Corbusier: Maniera ... cit. p. 9.

${ }^{13}$ Wogenscky, André; "Le projet pour Saint-Dié. Structure sociale et structure architectural" in Foundation Le Corbusier Paris: Le Corbusier. La Ville, l'urbanisme. Les rencontres de la foundation Le Corbusier. Rencontres des 9 et 10 jun 1995 ". Paris: Fondation Le Corbusier, 1995. pp. 62-72. (FLC-b).

${ }^{14}$ Musée de Saint-Dié: Le Corbusier... cit. p. 102. Also in Le Corbusier: "Un plan pour Saint-Dié" in L'Homme et l'architecture, Nn. 5-6, Novembre-Décembre. 1945, p. 44; in Werk, n.1, Jan. 1946, p. 112.

${ }^{15}$ Le Corbusier: "Il cuore ... cit. p. 52.

${ }^{16}$ Musée de Saint-Dié: Le Corbusier... cit. p. 37.
} 
the community life, and in which are arranged the residences and workplaces. The civic center is a center of gravity that unifies socially and morphologically: it is the city itself.

In drawing up the plan dated June 1945, the administrative tower is decentralized and occupies the north-east quadrant; the axis of connection is unique, underlines the existing main street, rue Thiers, and combines two religious units like two visual focus. In this first version, the civic space revolves around a central more concentrated and with greater hierarchy of empty squares. A second version, after a few months, shows a different orientation of the administrative high-rise, rotated ninety degrees and the hint of the second axis parallel to the main one, now partially intended vehicular crossing of the river and the connection with the road infrastructure bordering the center.

The museum of knowledge and the cultural area have the shape and position of the final version, while the area that will be dedicated to receptive is occupied by the constituent elements of the administrative area.

In the final version of the project there are two axis north-sud and so two visual focus: one axis links the church at south to administrative hide-rise that become the the main visual background, the other one parallel at first, focus on the cathedral through the cultural area and a sequence of differente voids, compressed and dilated. In this second visual axis, the direct link is only of vision and the pedestrian path between the figurative fragments is deviated. In this way, the main walking path remains what connects the elements, while a secon path frames, exalting it, the identity fragment, represented by the cathedral. This biaxial disposition sets up the urban heart by the connection between civic nucleus and religious nucleus, even more like in the medieval city.

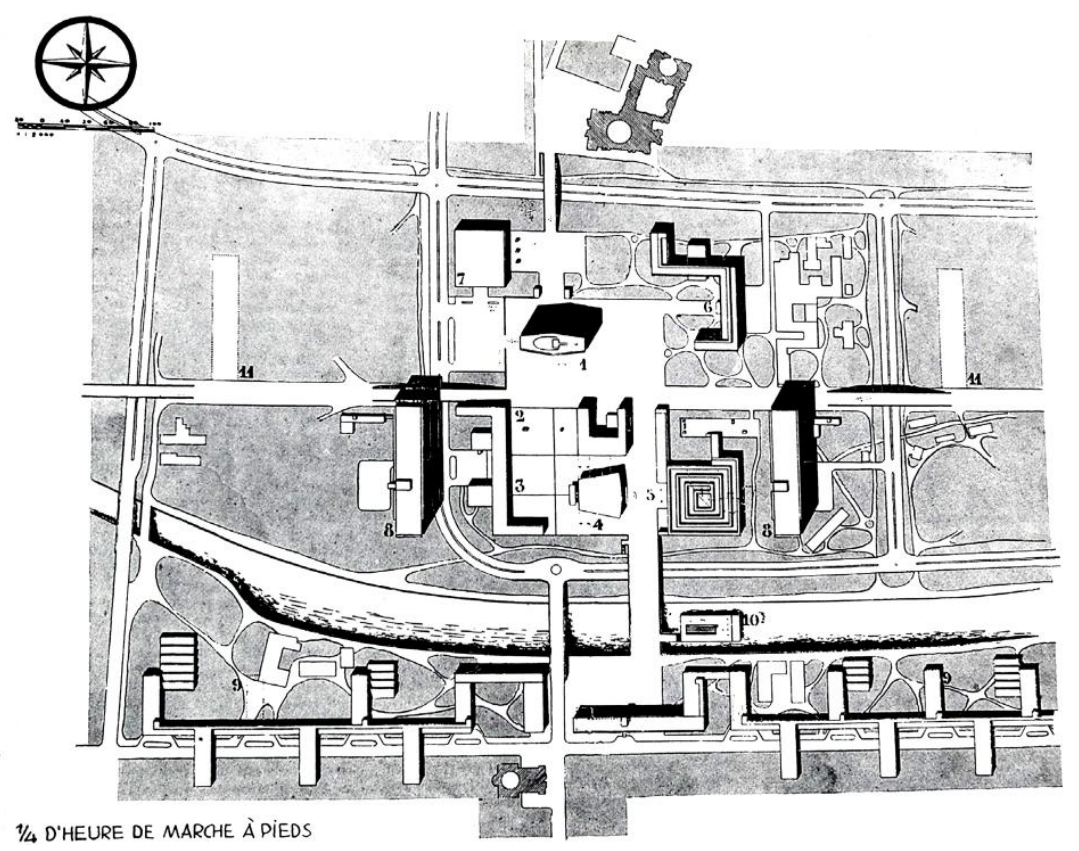

4. Le Corbusier, The civic centre of Sant-Dié, version of 1 January 1946.

Religious fulcrum and civic fulcrum, memorial elements of the past and objects of the present time, have the same urban significance. All the elements of the civic center are freely arranged on the basis of a grid with orthogonal mesh crossed by the nature and delimited a north and south by natural and building elements.

Also the factories, located on the left bank of the River Meurthe, are an essential part, economic and social, as well as a symbol and a necessity for the reconstruction. In the first sketch they are grouped to form a kind of urban wall that recreates a restraining margin between the center and the periphery; the subsequent hypothesis the units of production are a filter maintaining the effect of boundary and interface. 
The dwelling units are located in the north of plan. Here, the vertical garden-city and the horizontal garden-city coexist in the same place.

The continuity between the residence and the civic center is favored by a systematic pattern of roads that includes the total pedestrianization of area between them, thought mainly green.

The mobility system is also an application of theories mentioned in the Ville Contemporaine (1922) with main attention to hierarchy differentiation of roads and complex system connecting the city with the territory and urban parts. Also it is refer to Ville Radieuse (1932), where over the sharp division between the different systems of circulation, there is the mutual independence between buildings and roads, and the ground is an ideal plan of nature. There is also a recall to the concepts and theories about the industrial linear city and the Usine verte, like a new and better settlement.

The horizontal registers where are placed dwelling and working units, at north and south, generate a kind of filtering urban wall: a new urban limit in the territory that draw a new skyline. It is a limit that refer to medieval urban limit but with the peculiarities of the present time: it is curtain opened in and to the landscape.

Geometry and nature are not only compositional elements but also operational tools of cohesion and connection of whole set. Geometry is used as a measure proportional to calibrate weighted distances as well as means of union with the human dimension, as subsequently theorized even with the Modulor. Nature is the "fluid" compositional element able to mix and hold together the composition of autonomous pieces to obtain a new set, according to a defined shape and at the same time open to continuous developments.

The original urban settlement took into account the position suggested by the topography of the place itself, that is the most favorable geography indication for the settlement arrangement. So, selecting and retracing some existing urban signs, made even more apparent by the violent destruction of the war, emphasizing and reconnecting the urban development to specific anthropogeographic values and designing the new settlement starting from the same recognized principles of the existing, while excluding any imitative principles.

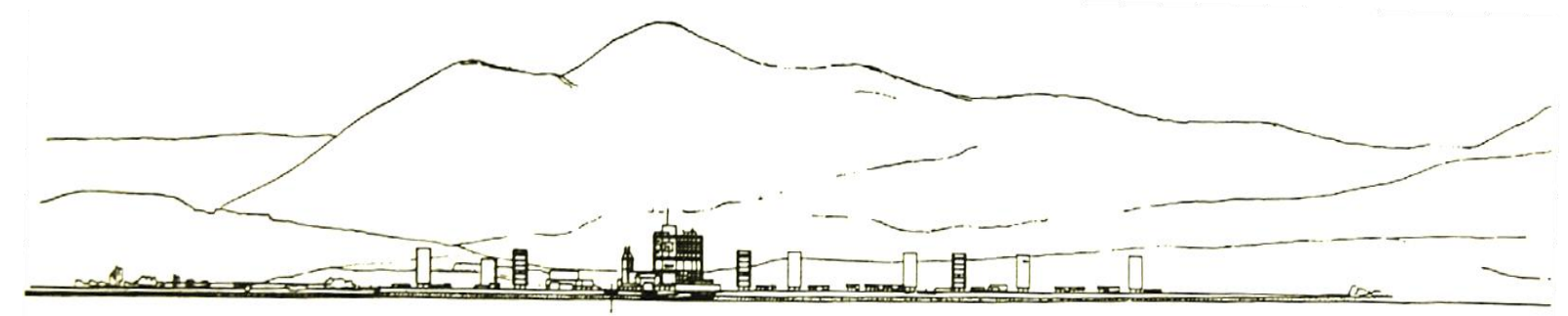

5. Le Corbusier, Skyline of Saint-Dié in the landscape showing the building of the first and second phases.

\section{Urban projects over the reconstruction}

In the same years of the project for Saint-Dié, Le Corbusier develops other reconstruction projects including Saint Gaudens, La Rochelle-Pallice ${ }^{17}$.

\footnotetext{
${ }^{17}$ Petrilli, Amedeo: L'urbanistica di Le Corbusier. Venezia: Marsilio, 2006. pp. 143-149.

See also: Le Corbusier: Euevre...cit. pp. 162-169. Le Corbusier: L'urbanistica dei tre insediamenti umani [1945]. Milano: Etas Kompass, 1961.
} 
Saint Gaudens is a small old Pyrenean town designated like site for the headquarters of the company that extracts natural gas from the Pyrenees. In his project of 1945-46, Le Corbusier suggests a town planning in three dimensions integrated to the landscape and considering primarily an overall territorial vision.

New settlements are arranged as autonomous nucleus around the little old town center. Two industrial plants are located next to the railway track in a bend of the river Garonne, flowing foot of plateau where the town lies.

A residential area for about 5000 inhabitants is planned west of the city, integrated to a large green area and with morphological elements dictated by topographical and environmental conditions and by landscape scenographic criteria. Another urban settlement is expected to the east and it is defined horizontal garden city.

The two housing developments, west and east, are connected to the historical settlement by an existing axis coming ut radially from the latter.

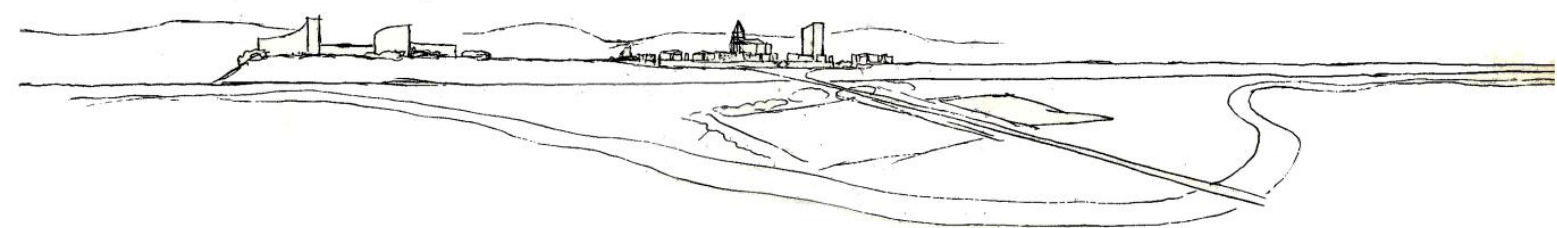

6. Le Corbusier, Skyline of Saint Gaudens in the landscape showing from left the new housing settlement, the civic and civil center and to more south, two new industrial establishments.

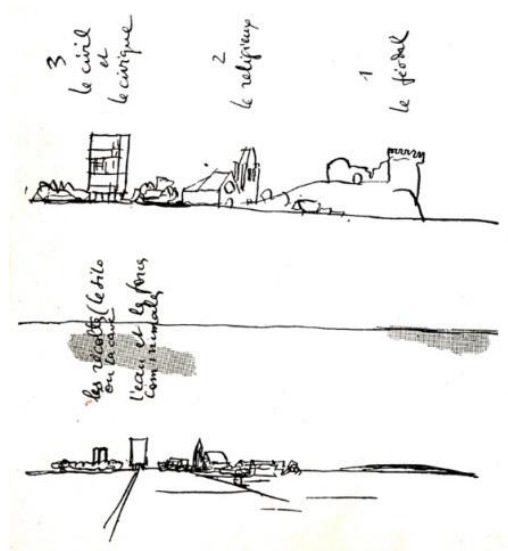

7. Le Corbusier, Sketch for the project of Saint Gaudens with the three compositive elements: the civic center, the religious nucleus and the medieval ruins.

Inside the old nucleus is concentrated any civic activity provided, primarily in a single tower building that is related in balance to mass and height, to the gothic cathedral and the ruins of the medieval castle.

Also in this occasion "the forms of the buildings will be determined by the conditions of the land, the horizons, the views and the orientation". [...] The old small town will see its centre of civic and civil forces rise up, its mass balancing that of the cathedral. ${ }^{18}$ Attention and interest in the historical pre-existence like vision fragments of urban composition characterize also the choices for the reconstruction plan of La Rochelle-Pallice. La Rochelle is a gothic town overlooking the Atlantic port; la Pallice is the neighboring industrial area link to the port and the railway system. Even though they had both been mined during the war, they remained intact. Le Corbusier hypothesizes the preservation of the historical city La Rochelle in its entirety, as a stand-alone

${ }^{18}$ Le Corbusier: Euevre...cit. p. 162. 
fragment of landscape to be linked to new housing and production developments. The old town is surrounded by a large green ring and linked by a circulation system to the new industrial green town and to vertical and horizontal garden city. Here, the green ground and the horizon vision are the connection of different elements in the territorial context.

The small historic towns are considered the nucleus, the renovated civic center and so the heart, of the new urban developments according to a geographical dimension scale. As well as the reconstruction project for Saint Dié, also the projects for Saint Gaudens and for Rochelle-La Pallice, will not be realized.

A few years after, between 1949 and 1953, Le Corbusier designs the pilot plan for Bogotá ${ }^{19}$, in collaboration with Josep Lluis Sert and Paul Lester Wiener. Bogotá is considered political, administrative and cultural core of a territory at geographic scale. This project is a kind of city model that summarizes several methodologies in order to consider simultaneously the main elements at urban, metropolitan and geographic scale, deducted from the analysis of the formal conditions of the existing city.

There are some compositional tools and theoretical applications in it, which are together for the first time. In particular, the civic center is an urban element that represents a new urban function, due to the reinterpretation of the center of power and the most important public space of the city in the Hispano-American urbanism; the urban sectors to divide the area according to regular pattern while taking account of the original morphology and their road hierarchy according to the rule of $7 \mathrm{~V}$, like indispensable framework for the circulation and the composition in intermediate scale.

Some aspects already investigated in the reconstruction project for Saint Dié return here: the presence of an urban center closed to traffic, around which the whole project is oriented and the presence of a pervasive nature that determines the cohesion, even perceptive, of the settlement at the foot of mountains, that form the background of it. Even in Bogotà, the urban project includes a sort of anthology of projects designed for other specific locations or only theorized, as weel as the central theme of housing, now refering also to the just built Unité d'Habitation in Marseille.

The analysis step makes to reference to the history, the topography and the envirement of the city; this step is followed by the superposition of a grid derived from the Carta d'Atene, as well as proposed in 1949 at CIAM 7 in Bergamo. The project step relates to more planning scales, under which four plans are developed: the regional plan, metropolitan plan, the urban plan and the civic center plan, considering the conservation of the historic area and most of the old buildings.

\section{“[...] Souvent, l'Euvre révolutionnaire se manifeste par un caractère hautement tradizionnaliste"20.}

The main civic and representative space is defined from renewing its center itself, around already plaza de Bolívar. From the first sketches, the urbanism in three dimensions is explicit: volumes and spaces overlap and confront directly with geography and history, taking into account new patterns of relationships which add to the

\footnotetext{
${ }^{19}$ Cf. Le Corbusier: Euevre Complete. 1936-1952. Zürich: Girsberger, 1945. pp. 42-45. See also: O'Byrne Orozco, Maria Cecilia (edited by): Le Corbusier en Bogotà 1947-1951. V. 1-2.. Bogotà: Fondation Le Corbusier; Universida de los Andes; Pontificia Universidad Javeriana, 2010. in particular the Fontana, Maria Pia; Mayorga, Miguel: "Arquitectura en todo, urbanismo en todo.Le Corbusier: del Centro Cívico al centro de Bogotá”, pp.82-101. See also: Rogers; Sert; Tyrwhitt: CIAM 8...cit. pp.150-152.

${ }^{20}$ From the technical documents for the project of pilot plan from archive German Samper in O'Byrne Orozco, Maria Cecilia (edited by): Le Corbusier en Bogotà 1947-1951. V.1. Bogotà: Fondation Le Corbusier; Universida de los Andes; Pontificia Universidad Javeriana, 2010. p. 3.
} 
established city order, superimposing a series of formal rules arising from the reinterpretation of pre-existing conditions.

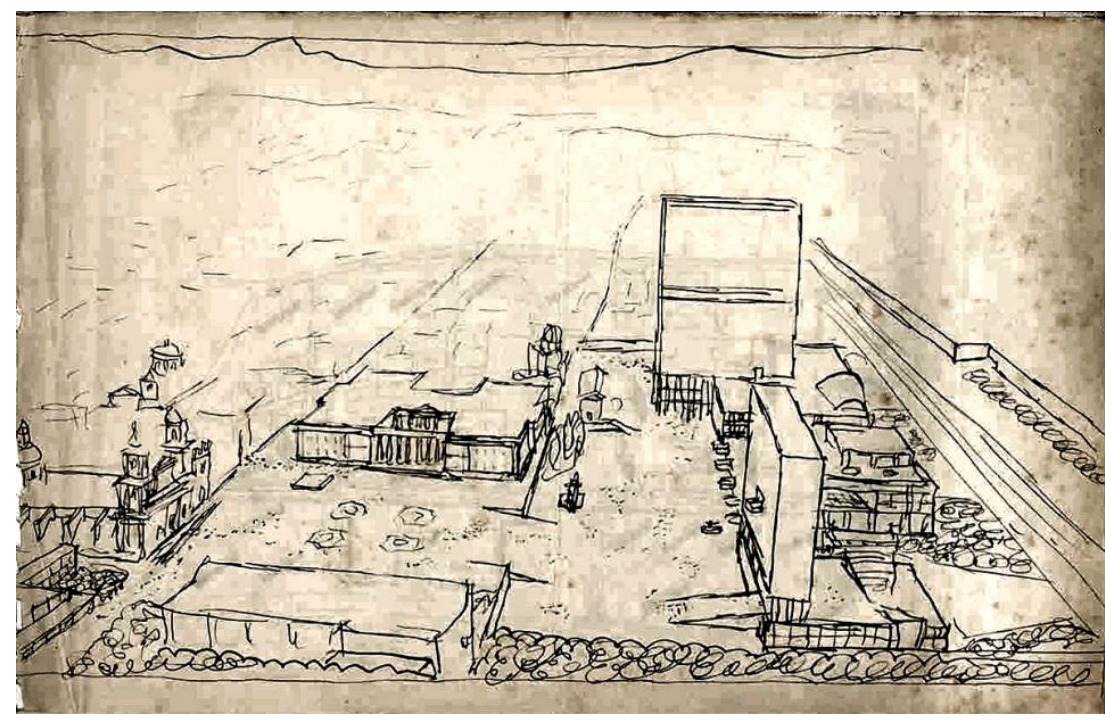

8. Le Corbusier, Sketch of civic center of Bogotá.

New architectural volumes overlap to the checkerboard pattern of the colonial city, emphasizing its relationship with the landscape in order their position and orientation, through a main urban axis, in the longitudinal direction,, that is also an visual axis. In the Civic Center, urban and regional heart, the urban-architectural approach is integrated and becomes more visible: the unit is governed by the mixture of elements from the geographical basis and forms of urban development of the existent historic center. It is verifies the new potentialities of the architecture to make town. The Civic Center is drawn into the mesh of sectors proposed for the city, structured by a linear system of three focal points of tension: Bolivar Square, an area south of the square and another north. Two new high buildings and some others significant preexisting, between them the cathedral and parliament palace, mark the void on different levels around the old colonial square, Plaza de Bolívar, looking for the balance relations also with other lower administrative buildings. The relantionship of new architectures with the landscape context, mainly with the mountains and with the historical and anthropogeographic heritage, is achieved by a calibrated study of position and dimension of all the compositional elements, whether natural or constructed elements, like a different fragments. So, it is also a scenographic project, where the human subject is at the same time actor and spectator: it is the costruction of a landscape in the territory. 


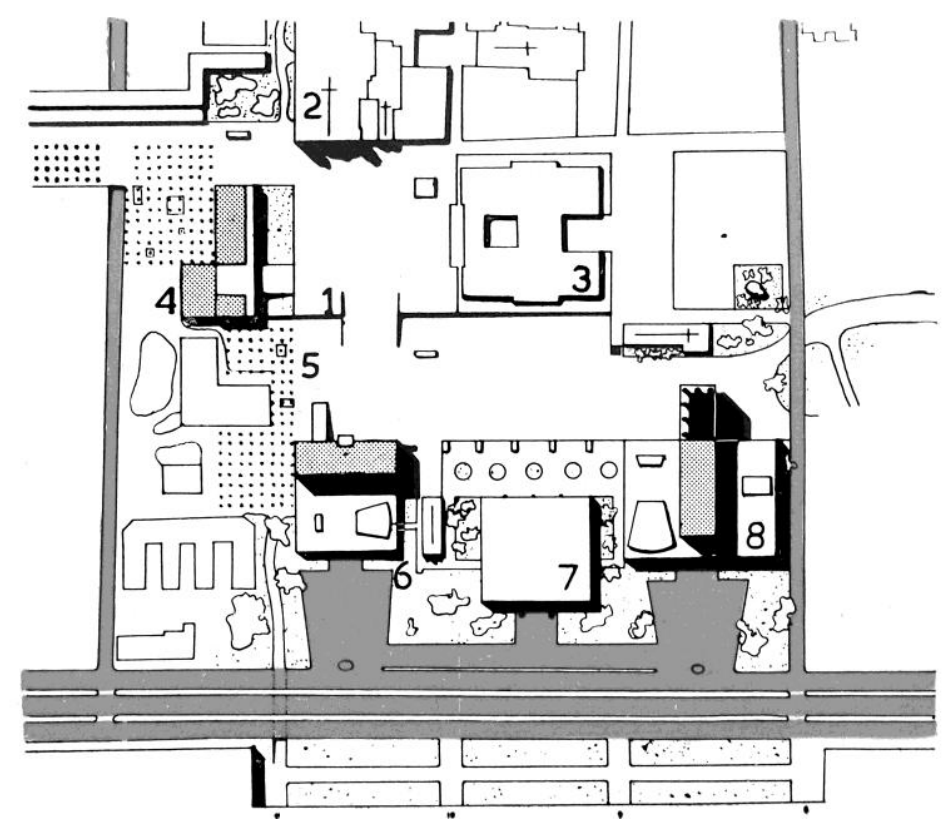

9. Le Corbusier, Plan of civic center of Bogotá.

\section{Conclusions}

"The city for Le Corbusier is not so much a reality as a representation, a collage of images"

In this kind of integrated plan, each building is a sign and a kind of visual pivot in the landscape: the city itself is considered a territorial signal and a civic core reconstituted in the new unit: a composition of calibrated visual resonances.

"There are mathematical points of consonance which might be called acoustic points of visibility, points of agreement where things take a decisive value. Just move a few steps because they do not have more: the relationship is gone, or we are out of range" ${ }^{22}$

The space, the void, rather than the object, is the key element for the place as a whole. These places where the agora coexist with the acropolis, where the voids are prevailing, a city of objects if compared at the traditional solid city as defined by Colin Rowe $\mathrm{e}^{23}$, are a kind of great machine à voir that allows the synthesis of arts and where is possible the symphony of things.

Natural elements and territory and anthropic elements, such as traces of the historic stratification, are considered in the same way part of a calculated scenic and phenomenological system.

They are fragments and frames at the same time.

The buildings, scattered on a large and not delimited surface, find a new cohesion through optical triangulations, dynamic but controlled, which determines the measure and relationship with the landscape.

\footnotetext{
${ }^{21}$ Colomina, Beatriz: Privacy and publicity: modern architecture as mass media. Cambridge (Massachusetts) - London: The MIT press, 1996. p. 319.

${ }^{22}$ Le Corbusier: Il cuore... cit. p. 46.

${ }^{23}$ Rowe, Colin; Koetter Fred: Collage city. [1978].Cambridge (Massachusetts) - London: The MIT Press, ( $8^{\circ}$ ed.) 1995. pp. 60-63.
} 
This plastic equilibrium is understood like a kind of balanced symmetry ${ }^{24}$. The scale of perception follows the criterion of scenic effect linked to the movement of the subject and the relative position of the architecture: a peripatetic vision, second the declension of greek picturesque described by Auguste Choisy ${ }^{25}$, in a composition of heterogeneous and discontinuous pieces with apparent disorder ${ }^{26}$ held together in unit with a balance generated between mass of volumes and relative intermediate space.

The perceptual relations are equilibrated by ponderal weights that are generated by the volumes and the space between them and the relations of the foreground and background figures established by reference to the moving subject that passes through them in predetermined promenades architecturales.

It is a kind of paratactic narrative that consists of poetic fragments, each of them referring to their whole, and where the landscape is the cohesion and the constitutive and operational device.

"Environment and landscape exist only through the eyes". ${ }^{27}$

In this methodological system, the historical references are sublimated and synthesized in a conceptual background as if they came from a "tools box" of personal memory, where are contained together to other past experiences, memory of different things and places, like organic forms, artistic works and Italian squares or other Mediterranean public spaces: a "box of the mind", in bulk, where they "float and ferment" ${ }^{28}$ to emerge through forms and compositions always new and different, as if the design process was always dynamically and tirelessly underway ${ }^{29}$.

In every case, the projects refer the general atmosphere of the context so that they establish a spatial and historic continuity of development. So, for example, also the project for the hospital of Venice is another type of proposal for an urban development in open form, like a mat, and in continuity with the conceptual traces of contiguous existing historical city.

In Saint-Dié, Bogotà, but also Chandigarh and then Firminy, the perceptual scale follows the criterion of scenographic effect linked to movement of the human subject and to the relative position of the architectures. Here, the buildings are scattered in a space not bounded: autonomous objects, monadic, as part of other totality and radiating centrifugal force, are monumental plastic sculptural forming pins of a city as landscape.

These urban landscape are thought of as a espace indicible ${ }^{30}$, a relation of agreement and harmony between nature and architecture, memory and present, in which buildings, objects à réaction poétique, establish an acoustic relation with the place.

The existing buildings and the new ones establish a relationship of dialogue between them and generate a narrative composition starting from memorial fragments. The "change", in this way, creates a new formal continuity. It is a reintegration into the historical process of the fragments of the past, physical traces of the time, according to new interpretations that allow the valorization of the diachronic and identity aspects at the same time purifying the fragments themselves from the feature of simple citational presences. The phenomenological

\footnotetext{
${ }^{24}$ Le Corbusier: Propos d'urbanisme. Paris: Bourrelier et C., 1946. pp. 17-18.

${ }^{25}$ Cf. Choisy, Auguste: Histoire de l'architecture. [1899]. Paris: Baranger, 1929.

${ }^{26}$ Ibidem

${ }^{27}$ Le Corbusier: Maniera...cit. p. 80.

${ }^{28}$ Wogenschy, André: Le mani di Le Corbusier. Roma: Mancosu Editore, 2004. p. 59.

${ }^{29}$ Cf. Rogers, Ernesto Nathan, Le Corbusier tra noi, Milano: All'insegna del pesce d'oro, 1966.

${ }^{30}$ Le Corbusier, "L'espace indicible" in L'Architecture d'Aujourd'hui. No Number, “Art”. Paris, April 1946. pp. 9-17.
} 
aspect and the human movement of the promenade establish a new narrative compositional unity. The equilibrium generated in the spatial dimension by balance weights, volumes like sized masses to which correspond calibrated distances, is also transposed in the temporal dimension like the relationship past - present.

The whole composition creates a dynamic of space-time, complex and not completely stated: an open urban work originated by poetic measure of architecture in landscape.

\section{Acknowledgements}

Thanks to the staff of Fondation Le Corbusier Paris and Inter-Library DIDA University of Florence. Immensely grateful to Claudia Conforti for the advises and to Vittorio Gregotti for the revision of research.

\section{List of images:}

1. Author: Le Corbusier. Fondation Le Corbusier - Paris, FLC 18440.

2. Author: Le Corbusier. Fondation Le Corbusier - Paris, FLC 18413.

3. Author: Le Corbusier. Fondation Le Corbusier - Paris, FLC 18450.

4. Le Corbusier: Euevre Complete. 1938-1946. Zürich: Girsberger, 1946. p. 139.

5. Le Corbusier: Euevre Complete. 1938-1946. Zürich: Girsberger, 1946. p. 134.

6. Le Corbusier: Euevre Complete. 1938-1946. Zürich: Girsberger, 1946. p. 163.

7. Ibidem and Le Corbusier: L'urbanistica dei tre insediamenti umani. [1945]. Milano: Etas Kompass, 1961. p. 107.

8. Rogers, Ernesto Nathan; Sert, Josep Lluis; Tyrwhitt, Jaqueline (edited by): CIAM 8. Il cuore della città: per una vita più umana delle comunità. Milano: Hoepli, 1954. p. 151.

9. Rogers, Ernesto Nathan; Sert, Josep Lluis; Tyrwhitt, Jaqueline (edited by): CIAM 8. Il cuore della città: per una vita più umana delle comunità. Milano: Hoepli, 1954. p. 152.

\section{Bibliography}

Choisy, Auguste: Histoire de l'architecture. [1899]. Paris: Baranger, 1929

Clericuzio, Peter: "Le Corbusier and the Reconstruction of Saint-Dié. The debate over Modernism in France, 1944-46" in The Chicago Art Journal, N. 20, 2010. pp. 46-71

Colomina, Beatriz: Privacy and publicity: modern architecture as mass media. Cambridge (Massachusetts) London: The MIT press, 1996

De Carlo, Giancarlo: Le Corbusier. Milano: Rosa e Ballo, 1945

Gerosa, Pier Giorgio: Le Corbusier, Urbanisme et mobilité. Basel - Stuttgart: Birkhäuser, 1978.

Le Corbusier: Le quatrês route. Terres, air, fer, eau. Paris: Gallimard, 1941

Le Corbusier: "Un plan pour Saint-Dié" in Homme et l'architecture, Nn. 5 - 6, Novembre-Décembre 1945

Le Corbusier: "Plans for the Reconstruction of France" in Architectural Record, N. 99, March 1946, pp. 92-93

Le Corbusier: "L'espace indicible" in L'Architecture d'Aujourd'hui. No Number, “Art". Paris, April 1946. pp. 9-17

Le Corbusier: "Ein Plan für Saint-Dié" in Werk, N. 33, April 1946, pp. 109-112

Le Corbusier: “A Plan for Saint-Dié” in Architectural Record, N. 100, October 1946, pp. 79-82 
Le Corbusier: Propos d'urbanisme. Paris: Bourrelier et C., 1946

Le Corbusier: Euevre Complete. 1938-1946. Zürich: Girsberger, 1946

Le Corbusier: Euevre Complete. 1936-1952. Zürich: Girsberger, 1952

Le Corbusier: L'urbanistica dei tre insediamenti umani [1945]. Milano: Etas Kompass, 1961

Le Corbusier: “A propos d'architecture d'accompagnement et de respect du passé”, [avril 1946], in Le Corbusier: Le passé à réaction poétique. Paris: Caisse Nationale des Monuments et des Sites, 1988

Le Corbusier: Maniera di pensare l'urbanistica. [1946]. Roma - Bari: Laterza, 1997

Musée de Saint-Dié: Le Corbusier et Saint-Dié, Musée municipal de Saint-Dié-des-Vosges, 14 octobre-10 novembre 1987. Saint-Dié: Musée municipal de Saint-Dié, 1987

O'Byrne Orozco, Maria Cecilia (edited by): Le Corbusier en Bogotá 1947-1951. V. 1-2.. Bogotà: Fondation Le Corbusier; Universida de los Andes; Pontificia Universidad Javeriana, 2010

Petrilli, Amedeo: L'urbanistica di Le Corbusier. Venezia: Marsilio, 2006

Rogers, Ernesto Nathan; Sert, Josep Lluis; Tyrwhitt, Jaqueline (edited by): CIAM 8. Il cuore della città: per una vita più umana delle comunità. Milano: Hoepli, 1954

Rogers, Ernesto Nathan, Le Corbusier tra noi, Milano: All'insegna del pesce d'oro, 1966

Rowe, Colin; Koetter Fred: Collage city. Cambridge (Massachusetts) - London: The MIT Press, ( $8^{\circ}$ ed.) 1995

Sequeira, Marta: Para um espaço público. Le Corbusier e a tradição greco-latina na cidade moderna. Ministério da Ciência, Tecnologia e Ensino Superior. Lisboa: Fundação Calauste Gulbenkian, Fundação para ciência e a tecnologia, 2012

Wogenscky, André; "Le projet pour Saint-Dié. Structure sociale et structure architectural” in Foundation Le Corbusier Paris: Le Corbusier. La Ville, l'urbanisme. Les rencontres de la Foundation Le Corbusier. Rencontres des 9 et 10 jun 1995. Paris: Fondation Le Corbusier, 1995

Wogenschy, André: Le mani di Le Corbusier. Roma: Mancosu Editore, 2004 